\title{
Projection of impacts of climate change on windthrows and evaluation of potential adaptation measures in forest management: A case study from empirical modelling of windthrows in Hokkaido, Japan, by Typhoon Songda (2004)
}

\author{
Kohei T. Takano ${ }^{1,2}$, Kosuke Nakagawa ${ }^{3}$, Masahiro Aiba ${ }^{1}$, Michio Oguro ${ }^{1,2}$, Junko Morimoto ${ }^{3}$, \\ Yasuto Furukawa ${ }^{3}$, Yoshio Mishima ${ }^{4}$, Kenta Ogawa ${ }^{5}$, Rui Ito ${ }^{6,7}$ and Tetsuya Takemi ${ }^{6}$ \\ ${ }^{1}$ Graduate School of Life Sciences, Tohoku University, Japan \\ ${ }^{2}$ Forestry and Forest Products Research Institute, Japan \\ ${ }^{3}$ Graduate School of Agriculture, Hokkaido University, Japan \\ ${ }^{4}$ National Institute for Environmental Studies, Japan \\ ${ }^{5}$ Rakuno Gakuen University, Japan \\ ${ }^{6}$ Disaster Prevention Research Institute, Kyoto University, Japan \\ ${ }^{7}$ National Research Institute for Earth Science and Disaster Resilience, Japan
}

\begin{abstract}
:
A windthrow refers to the uprooting and overthrowing of trees by the wind. Typhoons are a major cause of windthrows in Japan and are predicted to intensify under global warming. This study aimed to estimate the impact of climate change on windthrows and evaluate possible adaptation measures for sustainable forest management. We incorporated Typhoon Songda (2004) simulation experiments under current and pseudo-global warming (2075-2099, RCP 8.5 scenario) conditions with windthrow modelling in four natu$\mathrm{ral}$ and four artificial (Abies sachalinensis, Pinaceae) forests of Hokkaido. Unexpectedly, pseudo-global warming conditions decreased windthrow probabilities compared with current conditions for both forest types, presumably because wind speeds of the simulated typhoon weakened in Japan's high-latitude regions. Our results indicate that reconversion of artificial forests into natural forests largely decreased windthrow probability, providing a potential adaptation measure for improved forest management. To fully understand the range of climate-change effects on windthrow in Japan, future studies should use different climate scenarios and data from other typhoons, geographical regions, and forest types.
\end{abstract}

KEYWORDS windthrow risk; typhoon hazards; maximum wind speed; forest vulnerability; random forest modelling; machine learning

\section{INTRODUCTION}

'Windthrow' describes trees that are overthrown by wind. In Japan, low-pressure climatic events, including typhoons, are major causes of windthrows (Table 12 of Suzuki et al., 2009), which accounted for $73 \%$ of weather-related damage in Japanese forests during 2004-2012 (Forestry Agency of Japanese Government, 2014, 2016).

To date, Typhoon Marie (T5415) in 1954 caused the most

Correspondence to: Kohei T. Takano, Forestry and Forest Products Research Institute, Matsunosato 1, Tsukuba, Ibaraki 305-8687, Japan. E-mail: koheit@ffpri.affrc.go.jp damage, destroying approximately $26,800,000 \mathrm{~m}^{3}$ of trees in an estimated area of 750,000 ha in Hokkaido, the northernmost prefecture in Japan (Tamate et al., 1977). Typhoon Songda (2004) caused the second-severest damage in Hokkaido, destroying a 36,956-ha forest area (Tsushima et $a l ., 2004)$. Compared to forests of southern Japan, those of northern Japan seem to be more vulnerable against typhoon hazards, presumably because northern Japan is hit by typhoons less frequently: The normal annual frequency of typhoon approach is 7.4 times in Okinawa (southern Japan), 3.1 times in Kanto (central Japan), and 1.8 times in Hokkaido (Japan Meteorological Agency, 2016). However, once the area is struck by a typhoon, forests can be seriously damaged.

In 2016, three typhoons struck Hokkaido for the first time in recorded history, and another typhoon pathed offshore of southern Hokkaido. Moreover, Murakami et al. (2012) predicted under the A1B scenario that, although the genesis of tropical cyclones will decrease in the western North Pacific during 2075-2099, intense tropical cyclones will rise in frequency. Therefore, it is becoming more important for sustainable forest management to estimate impacts of anticipated climate change on windthrows in forests of northern Japan, of which vulnerability is potentially high.

Risk of climate-related impacts results from the interaction of climate-related hazards (e.g. frequency and intensity of typhoons) with the vulnerability (e.g. vulnerability against windthrows according to forest types) and exposure (e.g. location of forests) (Intergovernmental Panel on Climate Change, IPCC, 2014). Changes in both the climate system and socioeconomic processes (e.g. forest management) are drivers of hazards, exposure, and vulnerability (IPCC, 2014).

Wind exposure was often represented with topographic exposure indices because direct wind data were unavailable in many previous studies (Mitchell and Ruel, 2015, but see e.g. Usbeck et al., 2011 and Klaus et al., 2011). If topographic exposure is used, however, it is difficult to separate effects of hazards and exposure in climate-change impact

Received 23 September, 2016 Accepted 4 December, 2016 Published online 28 December, 2016

C 2016 , Japan Society of Hydrology and Water Resources. 
assessments. Recently, simulated wind data became available by Ito et al. (2016) through numerical experiments conducted on Typhoon Songda (2004) under current and future climate conditions to examine how a pseudo-global warming climate affects typhoon intensity and windstorms in high-latitude regions.

As for vulnerability, Nakagawa et al. (2015) and Nakagawa (2016) conducted windthrow modelling using a random forest method incorporating the simulated wind data under current climate in Hokkaido, focusing on differences in vulnerabilities of natural and artificial forests. This model inferred the following: 1) windthrow ratios (i.e. probability of windthrow occurrence predicted by random forest modelling) are higher in artificial than in natural forest stands; 2) windthrow ratios monotonically increase with tree density, tree height, and maximum wind speed; 3) windthrow ratios have U-shaped relationships with TOPEX (distance limited topographic exposure; Ruel et al., 1997) and the slope angle (Nakagawa, 2016).

In the present study, we incorporated wind data (i.e. hazardous events and trends) from Ito et al. (2016) and hypothetical forest conditions (i.e. vulnerabilities) into the windthrow model of Nakagawa (2016), aiming to project the impact of climate change on windthrows and to evaluate possible adaptation measures in forest management. The novelty of our study is that we conducted climate impact assessments of windthrow using simulated wind data under current and pseudo-climate conditions in Asia for the first time. The projection in this study is also applicable to silvicultural planning (e.g. reconversion of artificial forests into natural forests) aimed at increasing forest management efficiency in Japan, where rapid depopulation and lack of forestry labour are expected (National Institute of Population and Social Security Research, 2013).

\section{MATERIALS AND METHODS}

\section{Data preparation}

Four artificial and four natural forests were selected as study sites in Hokkaido, the northernmost prefecture of Japan (Figure 1). In the artificial forests, the predominant species is planted Sakhalin fir (Abies sachalinensis (F.Schmidt) Mast., Pinaceae), whereas broad-leaved tree species that naturally invaded from surrounding natural forests also sparsely exist there. In the natural forests, predominant tree species are Sakhalin fir, Japanese lime (Tilia japonica (Miq.) Simonk, Tiliaceae), and Japanese oak (Quercus mongolica var. grosserrata (Blume) Rehder \& E. H. Wilson, Fagaceae).

The area of study sites ranges between $4.91-43.34 \mathrm{~km}^{2}$. Aerial photographs of the study areas before (1998-2004) and after (2004-2009) Typhoon Songda were obtained from Forest Agency, Geospatial Information Authority of Japan, and Hokkaido Prefectural Government. These aerial photographs were orthorectified, and windthrown regions ( $>0.05 \mathrm{ha}$ ) were detected on GIS using stereoscopic viewing software (Easy Stereo View; PHOTEC, 2015). Tree height and density (all trees and broad-leaved trees only; $n /$ ha) for each forest compartment (i.e. a management unit) were obtained from registration data. For the two natural forests without registration data, these variables were estimated using aerial photography (see Nakagawa, 2016 for details).

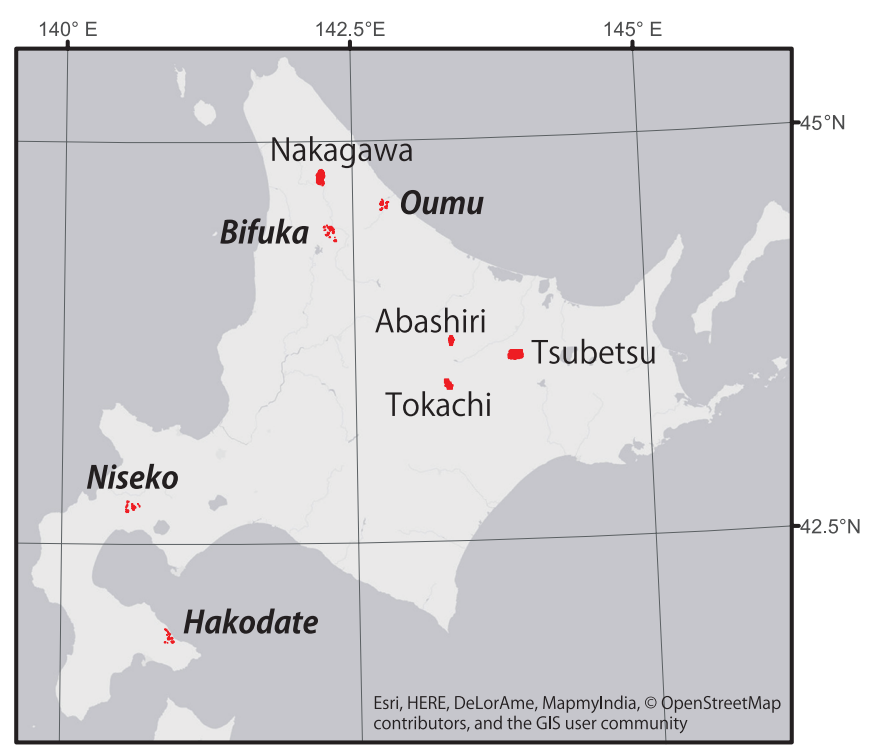

Figure 1. Study site locations (in red). The names of natural forests are indicated in plain font and those of artificial forests in bold italic

Distance limited topographic exposure (TOPEX; for 2,000 m in 100-m intervals) and the slope angle were calculated from a digital elevation model with a $10-\mathrm{m}$ resolution (Geospatial Information Authority of Japan, 2011). TOPEX is calculated by scanning the surrounding landscape for maximum angles from a given pixel. Maximum angles are measured for each of 8 horizontal direction classes and those maximums are summed for the final score. A positive TOPEX value indicates a sheltered topography whereas a value of 0 indicates a flat plain and a negative value indicates an exposed topography.

Grid intervals of the numerical experiments for Typhoon Songda (Ito et al., 2016) was further downscaled from $1 \mathrm{~km}$ to $200 \mathrm{~m}$ for the current study areas. We applied the two-way nesting technique between the parent $(1 \mathrm{~km})$ and the child $(200 \mathrm{~m})$ domains. Then the maximum wind speeds from 0300 UTC on 7 September to 0000 UTC on 9 September were recorded for each grid cell.

Polygons of windthrown areas and forest compartments and grid cells of topographic data (TOPEX and slope angle) and maximum wind speed were intersected into $25 \times 25 \mathrm{~m}$ grid cells $(n=227,315)$. Above data preparations were conducted using a variety of GIS programs (QGIS 2.8.4, QGIS Development Team 2015; GRASS 6.4, GRASS Development Team 2012; ArcMap 10.0, ESRI 2010).

Grid cells with unrealistic values (e.g. density of all trees $<$ density of broad-leaved trees and negative values in the forest registration) were removed, reducing the sample size to 221,538 ( $n=40,934$ for artificial and $n=180,604$ for natural forests). Tree height and density were identical for each forest compartment because that is the smallest scale available from the registration data.

To avoid model bias that can occur when explanatory variables are dependent on forest size, we generated a subsample for modelling. First we removed forest compartments with less than 30 grid cells. Next, 30 grid cells were randomly sampled from each forest compartment while fixing the windthrow ratio. The subsequent windthrow model used the resultant subsample $(n=46,950)$. 


\section{Windthrow modelling}

We applied the random forest method (Breiman, 2001) to model windthrow occurrence. This method is a machinelearning technique that assembles numerous relatively independent decision trees. Forest type (artificial or natural) and study sites (as nominal variable, $n=8$ ) were incorporated into the model along with the six explanatory variables described under 'Data preparation' (maximum wind speed, tree height, density of all trees, density of broad-leaved trees, TOPEX, and slope angle).

As tuning parameters of random forest, ntree (number of decision trees to grow) was set to 500. Additionally, mtry (number of variables randomly sampled as candidates at each split) $=2,3,5$ and nodesize (minimum size of terminal nodes) $=2,5,10$ were examined. After a 10 -fold cross validation, $m$ try $=5$ and nodesize $=5$ were selected as the best combination in terms of the Matthews correlation coefficient (MCC: Matthews, 1975).

For detailed ecological interpretations of our model, see Nakagawa et al. (2015) and Nakagawa (2016).

\section{Model validation}

A 10-fold cross-validation was conducted and several model predictability indices were calculated. A threshold value of windthrow occurrence was determined with the coords function in the $\mathrm{R} p R O C$ package (Robin et al., 2011). This threshold is based on Youden's J statistics (sensitivity + specificity: Youden, 1950) and divides windthrow occurrence with non-occurrence. These were AUC (area under the curve of receiver operating characteristic (ROC); Swets, 1973), accuracy ([true positives + true negatives]/total $n$ ), sensitivity (true positives/[true positives + false negatives]), specificity (true negatives/[false positives + true negatives]), positive predictive value (true positives/[true positives + false positives]), negative predictive value (true negatives/ [false negatives + true negatives]), MCC, and informedness (sensitivity + specificity -1 ; Powers, 2011). True positive represents a case where both actual and prediction are positive, false positive represents where actual is negative but prediction is positive, false negative represents actual is positive but prediction is negative, and true negative represents where both actual and prediction are negative. These predictability indices were then compared to indices from previous studies.

\section{Prediction of global warming effects and evaluation of potential adaptation measures}

We predicted windthrow probabilities assuming various hazard intensities (i.e. maximum wind speeds of typhoons under current and pseudo-global warming conditions) and vulnerabilities (forest types and silvicultural scenarios).

To obtain the wind intensity of a future typhoon, grid intervals of the numerical experiments for Typhoon Songda (Ito et al., 2016) were downscaled from $1 \mathrm{~km}$ to $200 \mathrm{~m}$ under the pseudo-global warming condition, and the maximum wind speed was recorded for each grid cell.

Three silvicultural scenarios for artificial forest management were set: 1) status quo, 2) increase density of broadleaved trees to $\geq 100 /$ ha in artificial forests (Hokkaido Prefectural Government, 2014), and 3) reconvert artificial forests into natural forests (Forestry and Forest Products
Research Institute, FFPRI, 2012).

In the first scenario, the status quo was maintained for forest conditions for each grid cell. In the second scenario, broad-leaved tree density in the artificial forests were changed to 100 /ha for grid cells where the original values $<100$, whereas $\geq 100$ values were maintained. For the third scenario, artificial forest types were replaced with 'natural forest' as a factor. Additionally, tree height and density in artificial forests were replaced with the corresponding median values from natural forests in the subsample. Topographic variables were maintained at status quo for all grid cells in all predictions.

To project climate change effects on windthrow risks and to evaluate potential adaptation measures, windthrow probability was predicted for each grid cell. Specifically, the windthrow model was applied to datasets consisting of different typhoon hazards (maximum wind speeds under the current and future conditions) and vulnerable conditions (artificial or natural forest types and hypothetical forests under the three silvicultural scenarios). All analyses were conducted with the randomForest package 4.6-12 (Liaw and Wiener, 2002) in R version 3.3.1 (R Core Team, 2016).

\section{RESULTS}

\section{Modelling and validation}

The mean windthrow ratio for all grid cells in the study area was 0.016 , ranging $0.001-0.106$ across study sites. The model estimate of windthrow prevalence (i.e. occurrence rate) was 0.017 . Model predictability indices $(\mathrm{AUC}=0.93$, accuracy $=0.93$, sensitivity $=0.80$, specificity $=0.93$, and informedness $=0.74$ ) were reasonably high compared to previous studies (Table I). However, the model's positive predictive value was low $(0.18)$.

\section{Predictions}

In artificial forests $(n=40,934)$, the estimated maximum wind speeds $($ mean $\pm \mathrm{SD}$ ) were $29.8 \pm 7.0$ and $23.8 \pm 6.2 \mathrm{~m} / \mathrm{s}$ under current and pseudo-global warming conditions, respectively; in the natural forests $(n=180,604)$, the wind speeds were $28.0 \pm 8.4$ and $24.2 \pm 6.6 \mathrm{~m} / \mathrm{s}$. On average, wind speeds decreased from the current to pseudo-global warming conditions by $6.0 \pm 4.6$ and $3.8 \pm 3.3 \mathrm{~m} / \mathrm{s}$ in the artificial and natural forests, respectively.

After simulating typhoon intensities, the distributions of windthrow probability predicted for each grid cell were compared among different typhoon hazards and forest management scenarios for each forest type (Figure 2). In comparing different typhoon hazards, pseudo-global warming decreased the percentage of grid cells with high windthrow probabilities $(\geq 0.5)$ from current conditions primarily in artificial forests $(0.48 \%$ to $0.07 \%$; the change was from $0.08 \%$ to $0.03 \%$ in natural forests; Figure 2). In comparing forest management scenarios, the percentage of grid cells with high windthrow probabilities $(\geq 0.5)$ were highest under the status quo $(0.48 \%$ and $0.07 \%$ under current and pseudoglobal warming, respectively), dropped slightly when increasing broad-leaved trees $(0.40 \%$ and $0.04 \%)$, and dipped further when reconverting to natural forest $(0.07$ and $0.00 \%$ ) (Figure 2). 
Table I. Comparison of model predictability indices between the present and previous studies

\begin{tabular}{|c|c|c|c|}
\hline Model predictability index ${ }^{* 1}$ & $\begin{array}{c}\text { Present } \\
\text { model }\end{array}$ & $\begin{array}{l}\text { Previous } \\
\text { studies } * 2\end{array}$ & References \\
\hline AUC of ROC & 0.93 & $0.38-0.79$ & Kramer et al. (2001), Schindler et al. (2009) \\
\hline Accuracy: $(a+d) / N$ & 0.93 & $0.68-0.90$ & $\begin{array}{l}\text { Kramer et al. (2001), Mitchell et al. (2001), Hanewinkel } \\
\text { et al. (2004), Peterson (2004), Hanewinkel (2005), Scott } \\
\text { and Mitchell (2005), Pasztor et al. (2015) }\end{array}$ \\
\hline Sensitivity: $a /(a+c)$ & 0.80 & $0.26-0.96$ & $\begin{array}{l}\text { Mitchell et al. (2001), Hanewinkel et al. (2004), } \\
\text { Hanewinkel (2005), Pasztor et al. (2015) }\end{array}$ \\
\hline Specificity: $d /(b+d)$ & 0.93 & $0.18-0.95$ & $\begin{array}{l}\text { Mitchell et al. (2001), Hanewinkel et al. (2004), } \\
\text { Hanewinkel (2005), Pasztor et al. (2015) }\end{array}$ \\
\hline Positive predictive value: $a /(a+b)$ & 0.18 & $0.31-0.43$ & Mitchell et al. (2001) \\
\hline Negative predictive value: $d /(c+d)$ & 0.996 & $0.86-0.91$ & Mitchell et al. (2001) \\
\hline Matthews correlation coefficient (MCC) & 0.36 & $0.28-0.31$ & Mitchell et al. (2001) \\
\hline Informedness (Sensitivity + Specificity -1 ) & 0.74 & $0.14-0.63$ & $\begin{array}{l}\text { Mitchell et al. (2001), Hanewinkel et al. (2004), } \\
\text { Hanewinkel (2005) }\end{array}$ \\
\hline
\end{tabular}

$* 1$ : $a$ : true positive, $b$ :false positive, $c$ : false negative, $d$ : true negative, $N: a+b+c+d$

*2: Some indices were calculated from original data by the present authors.

\section{DISCUSSION}

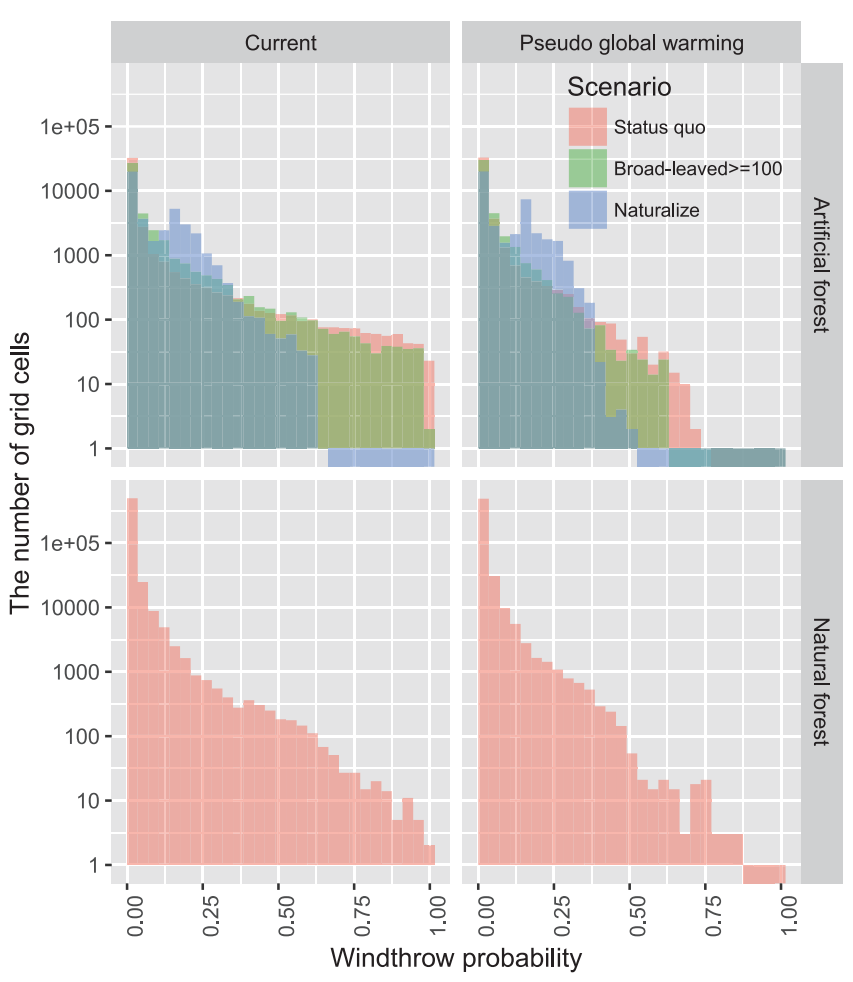

Figure 2. Histogram of windthrow probabilities predicted for each grid cell by the random forest model. The model included different typhoon intensities (maximum wind speeds under current conditions and pseudo-global warming during September of 2075-2099 in the RCP 8.5 scenario), forest types (artificial and natural forests), and silvicultural scenarios (status quo, increasing broad-leaved tree density to $\geq 100$ /ha, reconverting artificial forests into natural forests). The vertical axis is on a logarithmic scale. The colored area less than 1 indicates zero

\section{Impacts of climate change on windthrow}

Contrary to general expectations, the model predicted a decrease in windthrow risks under pseudo-global warming for both artificial and natural forests. The decrease in windthrow risks was considered mainly due to decrease in maximum wind speeds in most grid cells for both natural and artificial forests (Figure 3). Ito et al. (2016) gives some possible reasons for this outcome:

'The typhoon intensity at its maturity becomes stronger in a warming climate, and the typhoon while passing over the Sea of Japan weakens more rapidly in the warming climate. Thus the strong wind over the northern part of Japan in the warming climate also becomes weaker... It was found that the environmental meridional gradient of temperature at the $500 \mathrm{hPa}$ level is smaller in the warming climate than in the current climate, which indicates that the baroclinicity becomes weak under global warming. The weak baroclinicity makes the typhoon environment unfavorable for the extratropical transition, and therefore, possibly reduces the severity of typhoon wind in northern Japan.'

Therefore, typhoon-related windthrow risks may be reduced under climate change in Japan's high-latitude regions depending on typhoon tracks.

\section{Evaluation of potential adaptation measures}

The primary objectives of windthrow models are to detect vulnerable forest conditions and improve forest management (Perera et al., 2015). For example, after the storm Kyrill damaged $3 \%$ of the forests in northwest Germany, Klaus et al. (2011) investigated factors affecting forest sensitivity to storm-induced destruction. Forests in the region are dominated by European beech (Fagus sylvatica), pedunculate oak (Quercus robur), Norway spruce (Picea abies) and Scots pine (Pinus sylvestris), and the work found that a high proportion of coniferous trees strongly increased a 


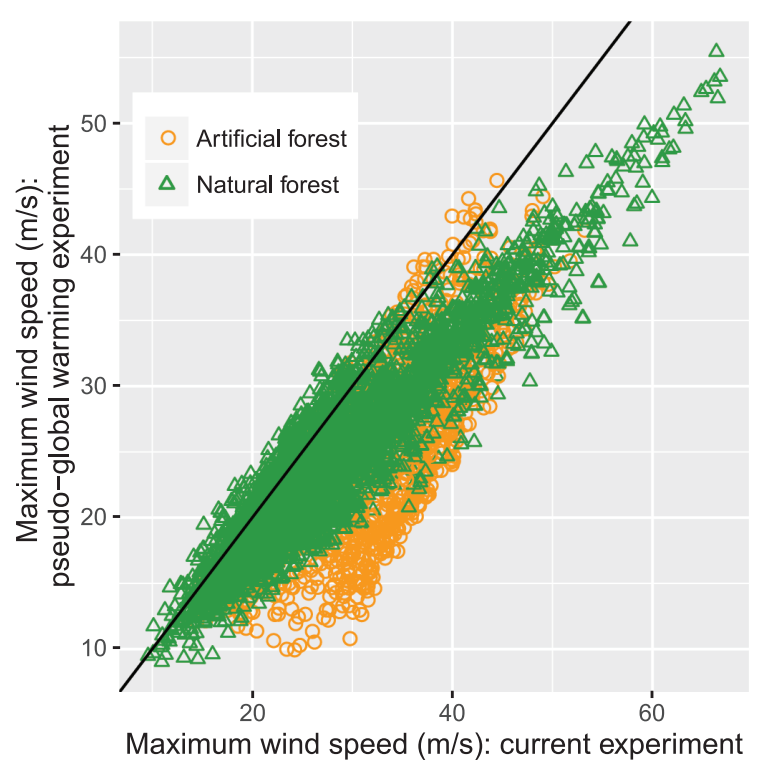

Figure 3. Comparison of maximum wind speeds simulated under current and pseudo-global warming conditions for each grid cell $(n=221,538)$ in the study sites in Hokkaido, northern Japan. Wind speeds were projected to decrease in the pseudo-global warming condition for most grid cells in both natural and artificial forests

stand's vulnerability to windthrow. In the present study, however, increasing broad-leaved trees (a modelling scenario that assumes preserving broad-leaved trees while harvesting planted coniferous trees) failed to greatly reduce the ratios of grid cells with high windthrow probabilities. Thus, a silvicultural operation that preserves broad-leaved trees at the expense of coniferous trees may have only a limited effect on enhancing tolerance of artificial Abies sachalinensis forests in Hokkaido against windthrows. For detailed ecological interpretations of our model, see also Nakagawa et al. (2015) and Nakagawa (2016).

In contrast, reconversion to natural forest decreased windthrow probabilities of most grid cells to below 0.5 . This modelling outcome is in line with our previous work showing that windthrow rate is significantly lower in natural forests (Nakagawa et al., 2015; Nakagawa, 2016). Furthermore, those previous analyses inferred that ridges and valleys are more vulnerable to windthrow than are flat areas. Together, these data suggest that prioritizing the reconversion of artificial forests to natural forests among steep ridges and valleys may be an effective windthrow countermeasure in Japan's high-latitude regions. Such strategies will increase forest management efficiency, which should especially benefit areas where rapid depopulation and lack of forestry workers are expected.

\section{Limitations and opportunities}

Our windthrow model outperformed many previous studies, and we considered our model valid for prediction. However, its positive predictive value was low, presumably because windthrow occurrence was extremely sparse $(1.58 \%)$ in the original data, inevitably raising the false negative ratio in the predictions. Our model is limited to judging windthrow occurrence or non-occurrence ( 1 or 0 ) based on a specific threshold of 0.035 . Therefore, we discussed potential risks based on windthrow probabilities (ranging from 0 to 1) predicted for each grid cell by the random forest model.

Furthermore, the model depends on the effects of only one typhoon in a relatively small area, limiting generalizations to other situations. The relationships between windthrow occurrences and their explanatory variables are complex, differing in response to numerous factors, including typhoon tracks, wind direction against slopes, and forest types (Klaus et al., 2011). For example, Hayashi et al. (2015) assessed the impact of Typhoon Songda (2004) in Tomakomai area of Hokkaido using satellite laser altimetry. They reported that the canopy height decreased (i.e. being disturbed by typhoon) most in artificial forests of Japanese larch (Larix kaempferi (Lamb.) Carr., Pinaceae), followed by Sakhalin spruce (Picea glehnii (F.Schmidt) Mast., Pinaceae) and Sakhalin fir. Hayashi et al. (2015) also found that serious damage occurred on gentle slope $\left(0-1^{\circ}\right)$, which is consistent with the result of Nakagawa (2016), whereas little damage occurred on steep slope, which is inconsistent with Nakagawa (2016).

Therefore, a single case study is not enough to predict general trends in climate-change effects on windthrow risk in Japan. It may be of interest to future studies whether other typhoons will also decrease in intensity at high-latitude regions, as shown in the pseudo-global warming experiments of Typhoon Songda's impact on Japan (Ito et al., 2016). Another potential area to explore is whether the proposed forest management in this study will be effective against windthrow in artificial forests from other regions, containing different tree species such as Japanese cedar (Cryptomeria japonica, Cupressaceae). To address these questions fully, it is necessary to accumulate case studies of windthrow events that include different localities and typhoons (e.g. Typhoon Mireille in 1991, see also Takemi et al., 2016).

\section{ACKNOWLEDGMENTS}

We thank the Hokkaido Regional Forest Office of Forestry Agency and the Hokkaido Government's Bureau of Forestry for providing forest registry data. This work was conducted under the Program for Risk Information on Climate Change (SOUSEI Program) supported by the Ministry of Education, Culture, Sports, Science, and Technology-Japan (MEXT) and by JSPS KAKENHI Grant Number 24580034 to J.M. and GRENE-ei program by MEXT.

\section{REFERENCES}

Breiman L. 2001. Random forests. Machine Learning 45: 5-32. DOI: $10.1023 / \mathrm{a}: 1010933404324$.

FFPRI. 2012. Handbook of reconversion of artificial forests into broad-leaved forests: The program "Research and Development Projects for Application in Promoting New Policy of Agriculture, Forestry and Fisheries" from the Ministry of Agriculture, Forestry and Fisheries of Japan (No. 1904). Forestry and Forest Products Research Institute, Tsukuba. http://www2.ffpri.affrc.go.jp/labs/bl_pro_1/top.html. Last access September 8, 2016. *Title is translated by Takano KT. 
Forestry Agency of Japanese Government. 2014. Statistical handbook of government-managed forest insurance. http://www. maff.go.jp/j/tokei/kouhyou/sinrin_hoken/. Last access October 24, 2016. *Title is translated by Takano KT.

Forestry Agency of Japanese Government. 2016. Statistical abstract of forest and forestry, Part 2: Forest management and conservation. http://www.rinya.maff.go.jp/j/kikaku/toukei/attach/ pdf/youran_mokuzi-10.pdf. Last access October 24, 2016. *Title is translated by Takano KT.

Geospatial Information Authority of Japan. 2011. Basic map information. http://fgd.gsi.go.jp/download/menu.php\#. Last access October 24, 2016. *Title is translated by Takano KT.

Hanewinkel M, Zhou W, Schill C. 2004. A neural network approach to identify forest stands susceptible to wind damage. Forest Ecology and Management 196: 227-243. DOI: 10.1016/j. foreco.2004.02.056.

Hanewinkel M. 2005. Neural networks for assessing the risk of windthrow on the forest division level: a case study in southwest Germany. European Journal of Forest Research 124: 243-249. DOI: 10.1007/s10342-005-0064-8.

Hayashi M, Saigusa N, Oguma H, Yamagata Y, Takao G. 2015. Quantitative assessment of the impact of typhoon disturbance on a Japanese forest using satellite laser altimetry. Remote Sensing of Environment 156: 216-225. DOI: 10.1016/j. rse.2014.09.028.

Hokkaido Prefectural Government. 2014. Retention Experiment for plantation FoREstry in Sorachi, Hokkaido (REFRESH). http://www.pref.hokkaido.lg.jp/sr/dyr/REFRESH/top.htm. Last access August 30, 2016.

IPCC. 2014. Summary for policymakers. In: Climate Change 2014: Impacts, Adaptation, and Vulnerability. Part A: Global and Sectoral Aspects. Contribution of Working Group II to the Fifth Assessment Report of the Intergovernmental Panel on Climate Change, Field CB, Barros VR, Dokken DJ, Mach KJ, Mastrandrea MD, Bilir TE, Chatterjee M, Ebi KL, Estrada YO, Genova RC, Girma B, Kissel ES, Levy AN, MacCracken S, Mastrandrea PR, White LL (eds). Cambridge University Press, Cambridge, UK and New York, USA; 1-32.

Ito R, Takemi T, Arakawa O. 2016. A possible reduction in the severity of typhoon wind in the northern part of Japan under global warming: a case study. SOLA 12: 100-105. DOI: 10.2151/sola.2016-023.

Japan Meteorological Agency. 2016. Normal number of typhoons. http://www.data.jma.go.jp/fcd/yoho/typhoon/statistics/average/average.html. Last access October 25 2016. *Title is translated by Takano KT.

Klaus M, Holsten A, Hostert P, Kropp JP. 2011. Integrated methodology to assess windthrow impacts on forest stands under climate change. Forest Ecology and Management 261: 17991810. DOI: 10.1016/j.foreco.2011.02.002.

Kramer MG, Hansen AJ, Taper ML, Kissinger EJ. 2001. Abiotic controls on long-term windthrow disturbance and temperate rain forest dynamics in Southeast Alaska. Ecology 82: 27492768. DOI: 10.1890/0012-9658(2001)082[2749:ACOLTW] 2.0.CO;2.

Liaw A, Wiener M. 2002. Classification and Regression by randomForest. R News 2: 18-22.

Matthews BW. 1975. Comparison of the predicted and observed secondary structure of T4 phage lysozyme. Biochimica et Biophysica Acta (BBA) - Protein Structure 405: 442-451. DOI: $10.1016 / 0005-2795(75) 90109-9$.

Mitchell SJ, Hailemariam T, Kulis Y. 2001. Empirical modeling of cutblock edge windthrow risk on Vancouver Island, Canada, using stand level information. Forest Ecology and Management 154: 117-130. DOI: 10.1016/S0378-1127(00)00620-4.

Mitchell SJ, Ruel J-C. 2015. Modeling windthrow at stand and landscape scales. In Simulation Modeling of Forest Landscape Disturbances. Perera AH, Sturtevant BR, Buse LJ (eds). Springer International Publishing, Cham, Switzerland; 17-43. DOI: 10.1007/978-3-319-19809-5.

Murakami H, Wang Y, Yoshimura H, Mizuta R, Sugi M, Shindo E, Adachi Y, Yukimoto S, Hosaka M, Kusunoki S, Ose T, Kitoh A. 2012. Future changes in tropical cyclone activity projected by the new high-resolution MRI-AGCM. Journal of Climate 25: 3237-3260. DOI: 10.1175/JCLI-D-11-00415.1.

Nakagawa K. 2016. The effects of plantation on wind disturbance regime in the forest landscape. Master's Thesis, Hokkaido University, Sapporo, Japan; 40 (in Japanese).

Nakagawa K, Morimoto J, Furukawa Y, Takano KT, Aiba M, Oguro M, Mishima Y, Ogawa K, Ito R, Takemi T. 2015. Windthrow risk assessment in Hokkaido: effect by the typhoon 18th, 2004. Proceeding of Typhoon Workshop in Disaster Prevention Research Institute, Kyoto University, October 31November 1, 2015 Kyoto, Japan; 27-31 (in Japanese with English abstract).

National Institute of Population and Social Security Research. 2013. Population projections for Japan - A supplement to the 2012 revision (Commentary with ancillary projections). Population Research Series No. 327, National Institute of Population and Social Security Research, Tokyo.

Pasztor F, Matulla C, Zuvela-Aloise M, Rammer W, Lexer MJ. 2015. Developing predictive models of wind damage in Austrian forests. Annals of Forest Science 72: 289-301. DOI: 10.1007/s13595-014-0386-0.

Perera AH, Sturtevant BR, Buse LJ. 2015. Simulation modeling of forest landscape disturbances: An overview. In Simulation Modeling of Forest Landscape Disturbances, Perera AH, Sturtevant BR, Buse LJ (eds). Springer International Publishing, Cham, Switzerland; 1-15. DOI: 10.1007/978-3319-19809-5 1.

Peterson CJ. 2004. Within-stand variation in windthrow in southern boreal forests of Minnesota: Is it predictable? Canadian Journal of Forest Research 34: 365-375. DOI: 10.1139/x03257.

Powers DMW. 2011. Evaluation: From precision, recall and F-measure to ROC, informedness, markedness \& correlation. Journal of Machine Learning Technologies 2: 37-63. DOI: 10.9735/2229-3981.

Robin X, Turck N, Hainard A, Tiberti N, Lisacek F, Sanchez J-C, Muller M. 2011. pROC: An open-source package for R and $\mathrm{S}+$ to analyze and compare ROC curves. BMC Bioinformatics 12: 1-77. DOI: 10.1186/1471-2105-12-77.

Ruel J-C, Pin D, Spacek L, Cooper K, Benoit R. 1997. The estimation of wind exposure for windthrow hazard rating: comparison between Strongblow, MC2, Topex and a wind tunnel study. Forestry 70: 253-266. DOI: 10.1093/forestry/70.3.253.

Schindler D, Grebhan K, Albrecht A, Schonborn J. 2009. Modelling the wind damage probability in forests in Southwestern Germany for the 1999 winter storm 'Lothar'. International Journal of Biometeorology 53: 543-554. DOI: 10.1007/ s00484-009-0242-3.

Scott RE, Mitchell SJ. 2005. Empirical modelling of windthrow risk in partially harvested stands using tree, neighbourhood, and stand attributes. Forest Ecology and Management 218: 
193-209. DOI: 10.1016/j.foreco.2005.07.012.

Suzuki S, Yoshitake T, Goto Y. 2009. Values for forest damage caused by strong wind, heavy rain, snow and forest fire based on statistics compiled in Japan from fiscal year 1954 to 2003. Bulletin of FFPRI 8: 71-100 (in Japanese with English abstract).

Swets JA. 1973. The relative operating characteristic in psychology: A technique for isolating effects of response bias finds wide use in the study of perception and cognition. Science 182: 990-1000. DOI: 10.1126/science.182.4116.990.

Takemi T, Ito R, Arakawa O. 2016. Effects of global warming on the impacts of Typhoon Mireille (1991) in the Kyushu and Tohoku regions. Hydrological Research Letters 10: 81-87. DOI: $10.3178 / \mathrm{hrl} .10 .81$.

Tamate S, Kajiyama T, Sasanuma T, Takahashi K, Matsuoka H. 1977. On the distribution maps of forest wind damage by typhoon No. 15, 1954 in Hokkaido. Bulletin of the Government Forest Experiment Station 289: 43-67 (in Japanese with
English abstract).

Tsushima T, Sugano M, Terasawa K, Kihata Y, Abe T, Sato S, Mioka O, Hara H, Asai T. 2004. A preliminary report of damage by Typhoon. Koushunai-Kihou 137: 1-12. Hokkaido Research Organization, Forest Research Department, Forestry Research Institute. https://www.hro.or.jp/list/forest/research/ fri/kanko/kiho/pdf/kiho137-1.pdf. Last access October 24, 2016. *Title is translated by Takano KT.

Usbeck T, Waldner P, Dobbertin M, Ginzler C, Hoffmann C, Sutter F, Steinmeier C, Volz R, Schneiter G, Rebetez M. 2011. Relating remotely sensed forest damage data to wind data: storms Lothar (1999) and Vivian (1990) in Switzerland. Theoretical and Applied Climatology 108: 451-462. DOI: 10.1007/s00704-011-0526-5.

Youden WJ. 1950. Index for rating diagnostic tests. Cancer 3: 32-35. DOI: 10.1002/1097-0142(1950)3:1<32::aid-cncr2820 030106>3.0.co;2-3. 